The Michigan ACRL Chapter held two program meetings during the Midwest Federation of Library Associations Second Quadrennial Conference in Detroit, October 1-4. The first event was a BACCH US (Bevy of Academic Concerns Causing Headaches for US) where membership had a choice of topics in which they could participate. Each group was moderated by a discussion leader and participants were encouraged to be involved in as many areas as they desired. Some of the concerns were library technicians, security, copyright, the card catalog, OCLC, and serials.

The speaker at the second program meeting was Victoria E. Fox, affirmative action director, Eastern Michigan University. She discussed the latest developments in affirmative action guidelines. Madeline J. Trimby, chairperson, 1974/ 75 , presided at a short business session at which new chapter officers for 1975/76 were introduced. The new officers are Eugene Holtman, Eastern Michigan University, chairperson; Linda K. Hamilton, Michigan Library Consortium, chairperson-elect; and Carol Juth Gavasso, Hope College, secretary-treasurer.

The fall meeting of the Kansas Chapter was held at Salina, Kansas, October 6 and 7, 1975. One hundred and five librarians attended.

Arne Richards announced the acceptance of Kansas ASA Local Chapter of the Association of College and Research Libraries. The state librarian, Ernestine Gilliland, explained changes in state library functions. Monday evening, Dr. John Dahlquist gave a fascinating presentation on various interpretations of the American Revolution.

Informative workshops on the production of book catalogs and systems approach to serials management were conducted by Xerox University Microfilms. A library smorgasbord featured buzz sessions. Then librarians discussed common concerns as regents, private, and two-year schools. The luncheon speaker was Dr. Sarah R. Reed, new director of the School of Library Science at Emporia. Her topic was "Library Education, 1876-1976."

The fall meeting of the Western New York/ Ontario Chapter was held at Niagara County Community College (Sanborn, New York) on October 18, 1975. Seventy librarians met and during a morning business meeting selected the chapter name and adopted a chapter constitution and bylaws. Afternoon sessions were devoted to three aspects of library orientation:

1. Student orientation - a forum dealing with applied methods and demonstration of materials. Moderators were Janet Mouskey and Don Prichard (Erie County Community).

2. Staff orientation-panel dealing with familiarizing new library staff with the institution's procedures. The panel was headed by Mary Jane Platou (SUNY Buffalo).

3. Faculty/researcher orientation-a panel focusing on making other professionals aware of the services the library can offer. Moderated by Roseann Bellanca ( Canisius College).

Elections for chapter officers and committee chairpersons are being held in December, with an installation dinner planned for late January.

All inquiries about the chapter, requests for copies of the bylaws, or information about membership should be directed to Sharon Rosengarden, Chairperson, State University College at Buffalo, E. H. Butler Library, 1300 Elmwood Ave., Buffalo, NY 14222.

ACRL Membership

November 30, 1975

November 30,1974

November 30, 1973

\section{Library Building Survey}

Jerrold Orne, former director of the University of North Carolina library, has embarked on an exhaustive effort to identify and record every new academic library built in the period 1967-76, as a basis for a national record for the profession. Orne is contacting each academic library listed in his survey, which has appeared annually in the December 1 issue of Library Journal, asking for a check on the figures previously reported and for comments on the successes and failures of library building planning. Any four-year college or university which has had a building project completed in the ten-year period 1967-76, and which has not been contacted by Dr. Orne with a copy of his survey form is asked to send word to him at the School of Library Science, University of North Carolina, Chapel Hill, NC 27514. 